\title{
STANISŁAW STASZIC - POLSKI PIONIER IDEI INTEGRACJI EUROPEJSKIEJ
}

\section{WSTĘP}

Integracja europejska ma długą historię. Już w VI w. p.n.e. ideę utworzenia federacji niezależnych państw-miast greckich przedstawił Tales z Miletu. Król Franków Karol Wielki dążył do zjednoczenia państw chrześcijańskich ${ }^{1}$. W następnych stuleciach pojawiły się kolejne projekty utworzenia związku państw europejskich, opartego na koncepcji jedności kulturalnej, religijnej, gospodarczej, politycznej lub prawnej. W książce Integracja gospodarcza - narodziny i rozwój idei (1986) Fritz Machlup wymienił 122 ekonomistów, filozofów, polityków, królów i pisarzy, którzy tworzyli projekty bądź wdrażali w życie wizję zjednoczonej Europy wielu narodów, m.in.: Friedricha Lista, Gustave'a de Molinariego, Vilfredo Pareto, Paula Van Zeelanda, Jana Tinbergena, Wilhelma Röpkego, Pierre’a Uri, Jerzego z Podiebradu, Emerica Crucé, Napoleona Bonaparte, Victora Hugo, Winstona Churchilla, Roberta Schumana i Jeana Monneta².

Niestety, F. Machlup pominął polskich pomysłodawców zjednoczenia Europy. Należeli do nich m.in.: Stanisław Wawrzyniec Staszic, Adam Jerzy Czartoryski, Józef Maria Hoene-Wroński, Wojciech Bogumił Jastrzębowski oraz Władysław Sikorski. O S.W. Staszicu jako twórcy idei zjednoczonej Europy wspominali m.in.: Maciej Iłowiecki ${ }^{3}$, Irena Rutkowska ${ }^{4}$ oraz Janusz Płaczek ${ }^{5}$. Należy ubole-

1 Por. I. Rutkowska, Od wspólnot europejskich do unii europejskiej, cz. 1, Wydawnictwo Zachodniopomorskiej Szkoły Biznesu, Szczecin 1998, s. 5.

2 Por. F. Machlup, Integracja gospodarcza - narodziny i rozwój idei, PWN, Warszawa 1986, s. $248-514$.

3 Por. M. Iłowiecki, Dzieje nauki polskiej, Wydawnictwo Interpress, Warszawa 1981, s. 121.

4 Por. I. Rutkowska, Od wspólnot..., s. 7.

5 Por. J. Płaczek, Poczet wybitnych ekonomistów polskich XVIII-XX stulecia, Akademia Obrony Narodowej, Warszawa 2000, s. 24. 
wać, że propozycja polskiego myśliciela, jednego z najtęższych umysłów oświecenia, nie została dotychczas szerzej omówiona w literaturze ekonomicznej. Lukę tę wypełnia niniejszy artykuł.

\section{RYS BIOGRAFICZNY STANISŁAWA WAWRZYŃCA STASZICA*}

Stanisław Wawrzyniec Staszic urodził się 6 listopada 1755 r.w Pile. Ojciec Wawrzyniec był burmistrzem Piły, matka Katarzyna z Mędlickich również pochodziła z rodziny mieszczańskiej. Po ukończeniu szkoły średniej w Poznaniu Stanisław wstąpił do poznańskiego Seminarium Duchownego. W 1774 r. przyjął niższe święcenia kapłańskie, natomiast w 1778 r. ukończył studia teologiczne, ale nie został wyświęcony na kapłana i nie wykonywał obowiązków duszpasterskich. Mimo to otrzymał godność kanclerza kolegiaty szamotulskiej, która zapewniła mu stały dochód $\mathrm{z}$ dóbr jankowickich.

W 1779 r. udał się na studia uzupełniające do Lipska i Getyngi, ostatecznie jednak studiował fizykę i historię naturalną w paryskim Collége de France. Po powrocie do kraju w 1781 r. został guwernerem dzieci kasztelana inflanckiego hrabiego Jana de Mier.

Kilka miesięcy później S. Staszic opuścił Inflanty i przyjął obowiązki sekretarza i nauczyciela dzieci ekskanclerza wielkiego koronnego Andrzeja Zamoyskiego i księżnej Konstancji z Czartoryskich: Aleksandra, Anny, Stanisława i Andrzeja. W 1782 r. Akademia Zamoyska nadała mu stopień doktora obojga praw oraz powierzyła katedrę języka francuskiego. Obok działalności dydaktyczno-wychowawczej i pisarskiej prowadził - z pomocą ojca - działalność gospodarczą w Wiedniu, głównie spekulacyjny handel papierami wartościowymi oraz pożyczanie pieniędzy.

W marcu 1787 r. wydał anonimowo rozprawę pt. Uwagi nad życiem Jana Zamoyskiego, kanclerza i hetmana w.k. do dzisiejszego stanu Rzeczypospolitej Polskiej przystosowane (drugie wydanie poprawione ukazało się w 1789 r. pt. Poprawy i przypadki do ksiązki Uwagi nad życiem Jana Zamoyskiego). Wytknął w niej wady

Biografię S. Staszica opracowano na podstawie następujących publikacji: B. Limanowski, Stanistaw Staszic: życiorys, Wydawnictwo J. Mortkowicza, Warszawa [1920], s. 5 i nast.; Z. Chyra-Rolicz, Stanistaw Staszic, PWN, Warszawa 1980, s. 5 i nast.; B. Szacka, Stanistaw Staszic. Portret mieszczanina, Wiedza Powszechna, Warszawa 1962, s. 9 i nast.; B. Szacka, Stanistaw Staszic, Państwowy Instytut Wydawniczy, Warszawa 1966, s. 11 i nast.; J. Olejniczak, Stanistaw Staszic 1755-1826: jubileusz 250. rocznicy urodzin, Archiwum PAN, Warszawa [2005], s. 2-7; C. Bobińska, Wstęp, [w:] S. Staszic, Wybór pism, Spółdzielnia Wydawnicza „Książka”, Warszawa 1948, s. XIII-LIII, oraz Stownik biograficzny ekonomistów polskich od XIII wieku do potowy wieku XX, zebrał i oprac. Z. Gazda, Wyższa Szkoła Pedagogiczna im. J. Kochanowskiego w Kielcach, Kielce 1998, s. 152. 
ówczesnego szkolnictwa zakonnego, koncentrującego się na nauczaniu teologii i autorytecie starożytności. Uważał, że człowieka należy przygotować do myślenia i służby dla społeczeństwa, tzn. obrony kraju i wspólnej pracy, która tworzy bogactwo. Jego zdaniem, efektem reformy Komisji Edukacji Narodowej, która wprowadziła edukację publiczną, mieli być rozumni obywatele, tymczasem byli potrzebni, waleczni i pracowici. Najważniejszym obowiązkiem każdego obywatela jest pracowitość, która świadczy o użyteczności społecznej.

W styczniu 1790 r. ukazała się kolejna anonimowa rozprawa S. Staszica pt. Przestrogi dla Polski z teraźniejszych politycznych Europy zwiazzków i praw natury wypadajace, obnażająca źródła upadku państwa polskiego, do których zaliczył samowolę szlachty i magnaterii, egoizm, monopol posiadania ziemi oraz niezdolność do rządzenia i obrony kraju. Za przyczynę niedorozwoju kraju uznał upośledzenie miast. Ratunkiem miała być głęboka reforma państwa, prawne zrównanie mieszczan, i szlachty oraz mężczyzn i kobiet, a także nadanie chłopom wolności oraz zastąpienie pańszczyzny czynszem. Uzdrowienie rolnictwa warunkowało rozwój całej gospodarki.

Prawdopodobnie w 1797 r. rozstał się z rodziną Zamoyskich i osiadł w Warszawie, gdzie podejmował badania naukowe i wspierał finansowo naukę polską. Równocześnie prowadził badania geologiczne w Małopolsce, Kielecczyźnie i Karpatach oraz na Rusi Czerwonej, Mazowszu, Podlasiu i na Węgrzech. 16 listopada 1800 r. S. Staszic uczestniczył w posiedzeniu założycielskim Towarzystwa Przyjaciół Nauk w Warszawie. Rok później nabył - na nazwisko Anny Sapieżyny z Zamoyskich - dobra hrubieszowskie. Formalnie ich właścicielem stał się w 1811 r., a kilka lat później dobra te przekazał tamtejszym włościanom. W 1816 r. utworzył Hrubieszowskie Towarzystwo Rolnicze, działające do 1951 r. W dobrach tych wdrażał w życie idealną organizację społeczeństwa o charakterze prespółdzielczym - S. Staszic był więc prekursorem spółdzielczości wiejskiej w Europie. Nawykami wpajanymi członkom Towarzystwa były gospodarność, pracowitość i oszczędność.

Od października 1804 r. do czerwca 1805 r. zgłębiał swoją wiedzę przyrodniczą, chemiczną, etnograficzną i paleontologiczną w Paryżu. W lipcu i sierpniu 1805 r. prowadził terenowe badania geologiczne, meteorologiczne, przyrodnicze i etnograficzne w Tatrach. Wyniki tych badań złożyły się na opis struktury geologicznej naszego kraju, który zawarł w pracy O ziemiorództwie gór dawnej Sarmacji a później Polski (1806) oraz w fundamentalnym dziele pt. O ziemiorództwie Karpatów i innych gór i równin Polski, wydanym w 1815 r. Za ich sprawą S. Staszic został nazwany „ojcem polskiej geologii”.

Jako członek-założyciel TPN, a do sierpnia 1808 r. - prezes, sfinansował budowę pierwszej jego siedziby przy ul. Kanonia oraz pokrył połowę kosztów budowy (1819-1823) monumentalnego gmachu przy Krakowskim Przedmieściu, 
zwanego Pałacem Staszica. S. Staszic był również autorem pomysłu i fundatorem - odsłoniętego w 1830 r. - pomnika Mikołaja Kopernika.

W lutym 1807 r. S. Staszic został powołany na członka Izby Edukacyjnej, nadzorującej funkcjonowanie szkolnictwa w całym kraju. Jego celem było stworzenie powszechnego systemu oświatowego. Również w tym roku wydał anonimowo pracę pt. O statystyce Polski, zawierającą dane empiryczne dotyczące całej Rzeczypospolitej przed rozbiorami, jak również wizję zreformowanego, nowoczesnego kraju, w którym podzielono ziemię, właściciele ziemi zastąpili magnatów oraz zlikwidowano poddaństwo, a pracowici ludzie doskonalili rolnictwo, rękodzieło oraz handel.

W czerwcu 1807 r. został członkiem Dyrekcji Skarbowej, natomiast w listopadzie 1808 r. król saski i książę warszawski Fryderyk August powierzył mu stanowisko referendarza stanu przy Radzie Stanu. W następnym roku został Radcą Stanu. Działalność w resorcie oświaty S. Staszic kontynuował po upadku Napoleona i utworzeniu Królestwa Polskiego. Wraz z powołaniem Rządu Tymczasowego w czerwcu 1815 r. mianowano go radcą stanu oraz zaangażowano w Wydziale Oświecenia Narodowego, natomiast w grudniu tego roku został członkiem Komisji Rządowej Wyznań Religijnych i Oświecenia Publicznego.

W okresie tym napisał kilka rozpraw: Myśli o równowadze politycznej w Europie (1816), O przyczynach szkodliwości Żydów i środkach usposobienia ich, aby sie spoteczeństwu użytecznymi stali (1816), Kontrakt Towarzystwa Rolniczego Hrubieszowskiego w zamiarze udoskonalenia rolnictwa i przemystu oraz wspólnego ratowania się w nieszczęśiach (1816), Obrona funduszu edukacyjnego (1816) oraz Pochwata Andrzeja Zamoyskiego (1816). W pierwszej postulował zrzeszenie narodów słowiańskich pod berłem cara Rosji, w drugiej zaproponował rozwiązanie nabrzmiałej kwestii poprzez pełną polonizację Żydów.

W 1816 r. otrzymał nominację na członka Komisji Rządowej Spraw Wewnętrznych i Policji. Równocześnie powierzono mu funkcję dyrektora generalnego Dyrekcji Przemysłu, Handlu i Kunsztów. W jego gestii znajdowały się sprawy nauki, kształcenia zawodowego oraz rozwoju polskiego górnictwa, zakładów przemysłowych i dróg. Dla potrzeb krajowego górnictwa i hutnictwa w lutym 1816 r. utworzono - według pomysłu S. Staszica - Szkołę Akademiczno-Górniczą w Kielcach. W 1824 r. został powołany na stanowisko ministra stanu oraz na członka Rady Stanu.

Jednocześnie S. Staszic działał w warszawskich organizacjach charytatywnych, które wspierał finansowo, m.in. hojnie wspomógł Szpital Dzieciątka Jezus, Dom Zarobkowy, Instytut Głuchoniemych, klinikę Uniwersytetu Warszawskiego, Szpital św. Ducha oraz zakład pod wezwaniem św. Kazimierza. Jako członek i współtwórca wspomagał materialnie Warszawskie Towarzystwo Dobroczynności. 
Stanisław Staszic zmarł nagle z powodu apopleksji 20 stycznia 1826 r. Po nabożeństwie żałobnym w kościele św. Jana został pochowany na cmentarzu przy klasztorze kamedułów na warszawskich Bielanach. Mowę pożegnalną nad mogiłą wygłosił Fryderyk Skarbek.

\section{KONCEPCJA STADIÓW ROZWOJU LUDZKOŚCI}

Dziełem życia S. Staszica był Ród ludzki (3 vol., 1819-1820). Nad tym historiozoficznym i dydaktycznym poematem pracował 23 lata; pisał go od 1791 do 1814 r. W dziele tym - prawdopodobnie inspirowanym poglądami Voltaire'a, A. R. Furgota, J. L. d'Alemberta, M. J. Condorceta, G. L. Buffona, J. G. Herdera i B. H. Holbacha - zamierzał rozpropagować idee oświeceniowe, a także przedstawić prawidłowości rządzące rozwojem społecznym oraz wskazać warunki powstania idealnego społeczeństwa ${ }^{6}$. Biorąc pod uwagę sposób władania ziemią (ziemia, będąca podstawą egzystencji człowieka, determinuje inne zjawiska społeczne), wyróżnił pięć epok w dziejach ludzkości ${ }^{7}$.

Epoka pierwsza była epoką natury. Zdaniem S. Staszica rodzaj ludzki pochodzi od pierwszych rodziców, którzy stworzyli pierwsze ogniwo społeczne. Ich dzieci rozmnażały się i powiększały związki rodziców. Większe rodziny tworzyły pierwsze plemiona. Działania plemion koncentrowały się na zdobywaniu żywności i ochronie dzieci. Chociaż uzależnieni od siebie, wszyscy byli wolni i równi. Występujące między nimi nierówności wynikały z osobistych przymiotów. Członkowie plemienia użytkowali ziemię na jednakowych warunkach. Nieliczne potrzeby były zaspokajane w sposób naturalny. W poszukiwaniu żywności przenosili się z miejsca na miejsce, czyli prowadzili koczowniczy tryb życia. Wspólnie żyli, pracowali, odpoczywali, rozmnażali się, bawili i bronili, w harmonii z naturą i w pokoju. Tworzyli wielką rodzinę. Funkcje władzy wykonawczej oraz stróża sprawiedliwości pełniła cała wspólnota, na straży praw natury stał zaś ojciec ${ }^{8}$.

W epoce drugiej, zwanej epoką „dzierży”, człowiek stał się istotą rozumną, a zarazem okrutną, i utracił wcześniejszy związek z naturą. Ludzie zaczęli wykorzystywać ogień oraz ćwiczyć mowę i tworzyć język. Abstrakcyjne pojęcia oraz

6 O stworzeniu przez S. Staszica wizji idealnego ustroju społecznego pisali m.in.: B. Szacka, Stanistaw Staszic. Portret..., s. 163; eadem, Teoria i utopia Stanistawa Staszica, PWN, Warszawa 1965, s. 94-95, 214 i 230; J. Grzywicka, Ekonomiczne poglady Stanistawa Staszica, PWN, Warszawa 1957, s. 80; Z. Chyra-Rolicz, op. cit., s. 74, oraz Z. Łotys, Stanistaw Staszic-filozof i reformator spoteczny, seria „Studia i Materiały WSP w Olsztynie” nr 158, Wyższa Szkoła Pedagogiczna, Olsztyn 1999, s. 176, 178, 186 i 201-204.

7 Por. J. Grzywicka, op. cit., s. 67.

8 Por. S. Staszic, Ród ludzki, t. 1, oprac. Z. Daszkowski, przedmowę napisał B. Suchodolski, PWN, Warszawa 1959, s. 73-76, 88-101. 
troska o pożywienie na przyszłość zrodziły potrzebę posiadania. Najpewniejszym źródłem pokarmu okazały się zwierzęta. Oswojone zwierzęta stały się pierwszą ich własnością. Wynalazek ten zmienił życie człowieka. Myśl o własności owładnęła człowiekiem, była przyczyną ciągłych waśni i wojen. Ale jako właściciel, człowiek jest odpowiedzialny za powierzoną mu część natury, twierdził S. Staszic. Udomowiając dzikie zwierzęta, człowiek stał się pasterzem. Chciwi okrutnicy i tyrani zaczęli przejmować na własność przedmioty, które wcześniej należały do wszystkich. Dla powiększenia swej własności ludzie dopuszczali się zabójstwa i grabieży. Zabójcy i grabieżcy stawali się bohaterami. Dla ukojenia sumień wymyślali sobie bóstwa; ubóstwiali wszystko, co było tajemnicą natury. Ochrona stada wymagała większej grupy ludzi, dlatego też pasterze przemocą utrzymywali kobiety i dzieci. Ojcowie rodów stawali się wodzami, kapłanami i panami. Niektóre rody, złożone $\mathrm{z}$ nierobów i oszustów w dalszym ciągu zajmowały się łowiectwem. Ubytek zwierząt łownych w lasach zachęcał ich do grabieży zwierząt hodowanych przez pasterzy. Łupem łowców padały nie tylko trzody, ale również kobiety, które stawały się wspólną zdobyczą. Łowcy stali się największym zagrożeniem własności rodzin pasterskich. Od tego czasu niektórzy ludzie wymyślali, jak zdradą i przemocą zgładzić innych. Narzędzia stosowane do polowań ludzie wykorzystywali przeciw człowiekowi. Rozwojowi pasterstwa towarzyszył wzrost hord łupieżców, którzy grabili hodowców. Wówczas narodziła się myśl „dzierży”. Napady, grabieże i gwałty trwały tak długo, dopóki łowcy nie stali się panami i tyranami rodzaju ludzkiego. Ich grabież została usankcjonowana. Przez tysiące lat ludzie unikający ciężkiej pracy zawsze żyli najlepiej. Nazwali się szlachtą, rycerzami, baronami i hrabiami; królem stał się największy łupieżca, konstatował S. Staszic.

W epoce trzeciej („wielbożeństwa”, czyli politeizmu - ubóstwiania wszystkich rzeczy) niektórzy pasterze przekształcili się w rolników; byli oni wzorem ludzkości, pokoju i miłosierdzia. Ale ciężko pracujący rolnicy doświadczali wzgardy i nędzy. Powstanie rolnictwa zrodziło państwa i poddaństwo. Posiadanie („dzierż”) zwierząt zrodziło myśl posiadania ziemi. Dzierża nie był jej właścicielem z tytułu prawa, ale dzierżawcą z tytułu przejęcia siłą. Dzierż ziemi łączyła się z niewolą rodzaju ludzkiego. Zniewalając narody, despoci budowali zamki i grody. Ziemia, rozszarpana przez rody ludzkie, przestała być przestrzenią pokoju i żywności, stała się miejscem wojny i śmierci. Panami ziemi i narodów stali się królowie ${ }^{10}$. Dzierż zagłuszyła w człowieku poczucie człowieczeństwa i stworzyła okrutnika i zabójcę. Żądza dzierżenia ziemi skłaniała ludzi do zajmowania każdego jej kawałka. Pasterze - z natury przezorni - pozostali ze swoimi zwierzętami w górach. Pracowici rolnicy zagospodarowali niziny z żyznymi ziemiami. Drapieżni łowcy

\footnotetext{
Por. ibidem, s. 118-119, 131-145, 154, 160, 167, 190-199.
}

10 Por. ibidem, s. 246 i 251-252. 
pojawiali się tam, gdzie łatwo było o rozbój. Rody pasterskie i rolnicze uczyły się hodowli zwierząt i uprawy roli. W rodach łowców uczono grabieży, nienawiści do ludzi pracujących i pogardy dla pracy. Wykorzystując konie, łowcy mogli siać grozę oraz więcej i szybciej grabić pasterzy i rolników. Zjednoczone i zuchwałe hordy łowców wydarły rolnikom i stada, i ziemię, a ich samych ujarzmili. W bezlitosny i okrutny sposób niszczyli pracowite rody pasterskie i rolnicze, siali śmierć i niewolę. Myśl dzierży przyniosła - zdaniem S. Staszica - nieszczęście rodzajowi ludzkiemu ${ }^{11}$.

Epokę czwartą S. Staszic nazwał epoką „samodzierży”, czyli feudalną. Obawiając się słusznej zemsty, despoci i gwałciciele żyli w ciągłym strachu o utratę wolności, rodziny i majątku. Należało więc zneutralizować nienawiść i zemstę, opanować rozum niewolników. Dla zachowania władzy i przywilejów łupieżcy zostali wsparci przez kapłanów. Religia stała się narzędziem zniewolenia rodzaju ludzkiego; utrwalała niewolnictwo oraz uległość kobiet. Łupieżcy i kapłani stworzyli związek, który okazał się najstraszniejszym spiskiem w dziejach człowieka. To spodlenie ludzi było wbrew naturze, pisał autor Rodu ludzkiego. Dwa samodzierże stany posyłały całe narody na rzeź. Do dzierżenia ziemi uprawnieni byli wyłącznie szlachta i kapłani. Pierwotnie dzierż była dożywotnia, później była dziedziczona. W systemie feudalnym każdy szlachcic pragnął samodzierstwa, monarcha dążył do połączenia dzierżaw w jednodzierstwo. Kapłani objęli władzę sadowniczą oraz posiedli jedną trzecią ziemi. W epoce czwartej utrwalił się więc - niezgodny $z$ naturą - podział rodzaju ludzkiego na dwa stany; stan szlachecki z duchowieństwem oraz niewolnicy. Ci ostatni zostali pozbawieni jakichkolwiek praw, ciążyła na nich jedynie powinność. Kobiety - połowa rodzaju ludzkiego - zgodnie z wykładnią prawa i religii - zostały uznane za niewolnice. Pozbawione prawa dziedziczenia były przedmiotem handlu, spadków i nagród. Natomiast pozbawiony wszystkiego niewolnik był traktowany jak zwierzę. Ludzie z różnych części świata wyrzynali się z powodu kłótni samodzierżów o żony, wiarę, dumę, ziemię itd. Mniejsza część narodu (samodzierżcy) podporządkowali sobie większą część, która stała się ofiarą pierwszej. Samodzierżcy uprawomocnili gwałt, zbrodnię, rozbój i nieszczęścia. Podbój innych narodów nie spotykał się ze sprzeciwem, przeciwnie - przynosił szacunek. W językach narodów zapanował fałsz; gwałcicieli nazwano ludźmi honoru, łotrów - bohaterami, rozboje - wojną, spiski - traktatami, rodziny samodzierżców - narodem, zdrady, zmowy, grabieże i zabójstwa - polityką, niewolę - wolnością, rozkazy gwałcicieli - prawem, utrzymywanie gwałtu - rządem, wolę narodu - buntem, zabobony - religią, obrządki - moralnością itd. Celem klas uprzywilejowanych nie było dobro ogółu (po-

11 Por. S. Staszic, Ród ludzki, t. 2, oprac. Z. Daszkowski, przedmowę napisał B. Suchodolski, PWN, Warszawa 1959, s. 13, 73-90 i 104-106. 
wszechne), ale oszustwo i panowanie nad ludem wydziedziczonym z ziemi, czyli ludem zniewolonym. Klasa uprzywilejowana pogardzała pracą, hołdowała próżnowaniu. Daniny pobierali wyłącznie samodzierże, którymi obciążali zniewolony lud, sami zaś byli zwolnieni z jakichkolwiek ciężarów. Efektem wojen prowadzonych przez samodzierżców nie był nowy porządek, ale nowy gwałt i nieład. Najwięksi z uprzywilejowanych wyrządzali największe szkody ludzkości. Lud prosty, pozbawiony wszystkiego, w sytuacji zagrożenia niepodległości kraju, zapominał o krzywdach i bronił ojczyzny, składając w ofierze swoje życie ${ }^{12}$.

Piąta epoka dziejów rodzaju ludzkiego była epoką królów i carów, epoką despotyzmu, którą autor Rodu ludzkiego nazywał ,jednodzierstwem”. Najmocniejsze rodziny dążyły do ogarnięcia wszystkiego, czyli jednowładztwa. Jednorzędztwo było nieuniknioną, konieczną, a zarazem ostatnią fazą rozwoju narodów cywilizowanych, nawet narodów zrzeszonych. Na każdym etapie historii ludzkości występowała konieczność sprawowania władzy. Podział władzy - wedle S. Staszica jest nienaturalny, prowadzi do gwałtu. Jednorzędztwo musi znaleźć potwierdzenie w ustawodawstwie krajowym. Stworzenie odpowiednich instytucji utrwalających jednorzędztwo jest szczególnie ważne dla zachowania porządku w okresie zmiany władzy. Instytucja jednorzędztwa wymaga uregulowań prawnych oraz stworzenia instytucji działających we wszystkich sferach życia społecznego, umożliwiających osiągnięcie dobra powszechnego. Gwarantem jednorzędztwa jest prawo dziedziczenia. Chociaż ludzie z natury dążą do uspołecznienia, do życia w społeczeństwie, do stowarzyszania się, to jednak ciągle wszczynają kłótnie i wojny, które wypełniają całą historię ludzkości. Mimo to S. Staszic uważał, że umęczone i wyniszczone wojnami narody Europy dojrzały do stworzenia jednego związku sprzymierzonych. Ostatnim etapem dziejów ludzkości - przedstawionym w Ro$d z$ zie ludzkim - będzie zrzeszenie ludów Europy ${ }^{13}$.

\section{ZJEDNOCZENIE NARODÓW EUROPY}

Społeczeństwa ludzkie - zdaniem S. Staszica - nie są wytworem rozumu człowieka. Społeczeństwa są efektem natury i organizacji ludzi, których celem jest osiągnięcie dobrobytu. Wszystkie narody wypracowały własne zasady współżycia, ulepszane w długim procesie rozwoju. W każdym społeczeństwie istniała instytucja rodziny, własności, wspólnych dóbr, religia, rządzący, sądy, warstwy i klasy społeczne, narody, państwa, relacje między państwami i przymierza. Wspomniane

12 Por. ibidem, s. 109-117, 124, 128-130, 136-137, 150, 159, 162, 167-169, 191-192, 212-214, 226, 239-241, 274-275, 280-291, 299-319 i 336.

13 Por. S. Staszic, Ród ludzki, t. 3, oprac. Z. Daszkowski, przedmowę napisał B. Suchodolski, PWN, Warszawa 1959, s. 249, 272-277 i 282. 
rozwiązania i instytucje są regulowane przez prawo narodów. Stanowią one główne zasady cywilizacji, czyli uspołecznienia ludzi. Ich rozwój lub regres zależy od woli ludzi, szczególnie od rządzących, monarchów. Brak rozwoju w stosunkach społecznych, względnie jego hamowanie, prowadzi do zniszczenia lub zguby narodu. Prawa i instytucje są lepiej rozwinięte w krajach bardziej cywilizowanych. Przykładowo, w narodzie żydowskim stosunki międzyludzkie podporządkowane są spokojowi i szczęściu rodzinnemu oraz dobrym obyczajom. Eksponowanie obyczajów rodzinnych sprawia, że rozpusta, rozwiązłość, cudzołóstwo, obżarstwo i pijaństwo rzadziej występują wśród Żydów. Żydzi są więc bardziej wstrzemięźliwi niż narody europejskie, wśród których żyją. Jednakże Europejczycy przejmowali od nich korzystne rozwiązania prawne, likwidowali niewolnictwo i poddaństwo, klasy uprzywilejowane i uciskane, dyskryminację narodową i wyznaniową. Zdaniem S. Staszica było i jest wiele społeczeństw wierzących w jednego Boga, w których obowiązują jednakowe prawa i sprawiedliwość. Stworzyły one odpowiednie do tych praw instytucje. Stan rycerski został zastąpiony przez narodowe wojsko, równe jak cały naród. Wojsko narodowe, wolne od nadużyć, nie tylko chroni przed zagrożeniami zewnętrznymi, ale również jest gwarantem bezpieczeństwa wewnętrznego ${ }^{14}$.

Autor Rodu ludzkiego uważał, że z powyższych zasad cywilizacji musi się jeszcze wyłonić zupełnie nowe rozwiązanie, najbardziej fundamentalne. Rozwiązaniem tym będzie związek wielu krajów, czyli ogólne zrzeszenie narodów. Będzie to zasada rozwoju społeczeństwa, dopełnienie cywilizacji, ostateczne stowarzyszenie ludzkie, którego trwałość będzie usankcjonowana prawnie. Scalając wszystkie inne zasady cywilizacji, stanie się zasadą zachowawczą, gdyż zagwarantuje wszystkim narodom trwały pokój, poprzez trwałe związki zewnętrzne. Umożliwi to społeczeństwom cywilizowanym wszechstronny rozwój. Dotychczasowa historia ludzkości dostarcza dowodów, że w efekcie rozwoju cywilizacji powstawały rodziny, klany i narody. Rozwój cywilizacji rodu ludzkiego prowadzi do łączenia, stowarzyszania i zrzeszania narodów. Bez względu na granice państwowe, góry i morza, nastąpi połączenie pewnych części świata. Do zjednoczenia wszystkich narodów dąży również Europa ${ }^{15}$.

Zasadę zrzeszenia narodów S. Staszic nazwał zasadą zachowawczą, gdyż istniejące wcześniej podziały były źródłem permanentnych wojen, gwałtów, zagrożeń i prześcigania się liczebnością wojsk. Dzięki zrzeszeniu narodów mogą ustać wojny wynikające $z$ ducha walki, z dumy czy chęci panowania. W dotychczasowej historii Europy narody cywilizowane ginęły pod naporem barbarzyńskich hord. Główną przeszkodą stowarzyszania się ludzi, jednoczenia narodów, był - na każ-

14 Por. ibidem, s. 297-300.

15 Por. ibidem, s. 300-301. 
dym etapie cywilizacji - duch wyłączności, zarówno ziemi, jak i urodzenia, religii, handlu itp. Monopol handlu miał być - według przewidywań S. Staszica - najdłużej działającym i najtrwalszym hamulcem zrzeszenia się narodów. Tymczasem zasada zrzeszenia narodów jest zgodna z prawidłowością uspołeczniania się ludzi, stanowi elementarną zasadę cywilizacji. Mimo uporczywych przeciwności, zasada ta będzie torować sobie drogę, rozwinie się, zaistnieje i utrwali ${ }^{16}$.

Powyższa zasada cywilizacji od dwóch tysięcy lat jest stosowana w Chinach. Kraj ten zamieszkuje wiele połączonych narodów, żyjących w zgodzie, bez wojen. Wojsko strzeże granicę zrzeszonego cesarstwa. Wewnętrzny pokój sprzyja rozwojowi całej gospodarki, wszystkich gałęzi, od rolnictwa, poprzez rzemiosło, do handlu wewnętrznego. Wielkie cesarstwo powstało $\mathrm{w}$ drodze łączenia oddzielnych królestw poprzez zwycięskie kraje oraz związki sprzymierzonych królestw. W sfederowanych państwach chińskich obowiązują dwa języki: ogólny („urzędowy”) język chiński oraz język lokalny. Mimo licznych prób zerwania związku przez niektórych monarchów, zrzeszenie zdołało utrzymać ogólny porządek i jedność, chroniąc cały kraj przed wojnami wewnętrznymi. Zdaniem S. Staszica niejeden władca zrzeszonego cesarstwa miał urażoną dumę czy cierpiał z powodu utraty własnej niezależności i samowoli. Zwyciężyło jednak poświęcenie dla wspólnego dobra wszystkich Chińczyków, uwolnionych od największego nieszczęścia, jakim są ciągłe wojny. Ofiara utraconej niezależności czy dumy poszczególnych książąt i królów jest niczym w porównaniu z wiecznym pokojem wszystkich narodów cesarstwa Chin. Twórcy idei związku, m.in. Konfucjusz, przyczynili się do rozwoju cywilizacji, moralności i szczęścia milionów ludzi, którzy okazują im wdzięczność i pamięć. Związek zrzeszonych narodów chińskich doprowadził do niewyobrażalnego dla Europejczyka poziomu rozwoju rolnictwa, rzemiosła, handlu wewnętrznego, a nawet przemysłu. Regulacja rzek i budowa kanałów umożliwiły rozwój śródlądowego transportu wodnego. Chiny jako całość stanowią jednorodną osadę złożoną z miast i wsi. Wiele miast zamieszkują miliony mieszkańców. Autor Rodu ludzkiego nie miał wątpliwości, że w Chinach panowało powszechne szczęście. Społeczeństwo utrzymuje milionową armię, która strzeże granic przed barbarzyńskimi hordami. Niektóre warownie zostały nazwane wojskowymi miastami. Straż obywatelska strzeże bezpieczeństwa wewnętrznego ${ }^{17}$.

Funkcjonowanie zrzeszenia chińskiego regulują ustawy. Tworzą one cztery fundamentalne zasady:

1) każdy separatystyczny duch jest godny potępienia;

2) wszystkich obywateli obowiązuje jedna sprawiedliwość;

16 Por. ibidem, s. 301-302.

17 Por. ibidem, s. 302-307. 
3) terytorium Chin jest zamknięte dla nowych religii; dopuszczalne jest wyznawanie religii istniejących w okresie tworzenia zrzeszenia;

4) handel wewnętrzny może być prowadzony wyłącznie przez krajowców, co oznacza całkowity zakaz handlu dla obcokrajowców.

Konsekwentne przestrzeganie tych zasad znajduje potwierdzenie w wielowiekowym doświadczeniu, wypływa z głębokiej rozwagi, której nie brakuje rozsądnym i szczęśliwym Chińczykom. Wieczny pokój był dla nich celem nadrzędnym, przedkładanym nad wszystkimi celami tymczasowymi, a więc złudnymi korzyściami. Zgoda na zakładanie angielskich faktorii i prowadzenie handlu zagranicznego z Anglią doprowadziły do kłótni, podbojów i wojen, a nawet utraty niepodległości. Taki los spotkał narody Indii i Europy, które zostały rozdzielone i zniszczone przez angielski handel. Doświadczeni i ostrożni Chińczycy okazali się bardziej rozsądni niż inne narody ${ }^{18}$.

Zrzeszenie narodów i towarzyszący mu pokój nie jest więc wytworem idealnym. Zrzeszenie jest naturalną konsekwencją rozwoju cywilizacyjnego narodów, jest ich - konstatował S. Staszic - przeznaczeniem. Zrealizowana w praktyce idea przyniosła wielkiemu narodowi chińskiemu szczęście i bogactwo. Do podobnego zjednoczenia dojrzała już rozwinięta cywilizacyjnie Europa. Jednoczeniu się państw europejskich sprzyjają nawet warunki naturalne, tj. morza otaczające kontynent i rzeki na krańcach wschodnich ${ }^{19}$.

Idea zrzeszenia się narodów europejskich rodziła się w wielu umysłach, wielokrotnie przyświecała wielkim zwycięzcom i bohaterom. Dostrzegali oni potrzebę zjednoczenia poróżnionych i podzielonych narodów, utworzenia wspólnoty. Niestety, podejmowane wielokrotnie próby połączenia narodów zostały okupione ludzką krwią. Ofiary te usprawiedliwiano chęcią budowy szczęśliwego zrzeszenia narodów, które zazna wiecznego pokoju. Już starożytna Grecja była dostatecznie rozwinięta cywilizacyjnie ( $\mathrm{z}$ rozwiniętym rolnictwem, handlem, rzemiosłem, miastami, prawem, wojskiem, nauką i sztuką) i gotowa do wdrożenia w życie zasady tworzenia wewnętrznych związków. Na przeszkodzie Ligi Achajskiej oraz Ligi Amfitriońskiej stanęly egoistyczne interesy królów rozdrobnionych państewek oraz azjatyckie hordy, które zrujnowały wspaniałą cywilizację grecką. Również cywilizacja rzymska mogła zjednoczyć całą Europę. Ale zamiast umacniać oraz tworzyć praworządną państwowość, ulepszać cesarstwo wielu narodów, dokonano jego podziału na szkodę całej Europy. Podział cesarstwa ułatwił ekspansję barbarzyńskich i germańskich hord, które zniszczyły cywilizację rzymską. Namiastką zrzeszenia narodów europejskich było państwo polskie, stanowiące wschodnie przedmurze Europy. Dzielni Polacy bronili Europy przed naporem azjatyckich

\footnotetext{
18 Por. ibidem, s. 307-308.
}

19 Por. ibidem, s. 309. 
hord, dzięki czemu narody zamieszkujące zachodnią część kontynentu rozwijały swoje gospodarki i siedziby. Rozdrobnione księstwa łączył w jedno Cesarstwo Frankońskie Karol Wielki. Chociaż jego dzieło stanowiło grunt dla trwałego zjednoczenia Europy, to jednak zostało rozerwane przez ducha niezależnego panowania. Jeszcze większy postęp dokonał się za sprawą Napoleona, który wprowadził myśl jednorządztwa. We wszystkich zjednoczonych przez francuskiego cesarza narodach obowiązywały zasady konstytucyjne, uregulowane kodeksem Napoleona, które gwarantowały prawa własności oraz likwidowały przywileje, dyskryminację i podział społeczeństwa, wprowadzały wspólne sądy. Wszystkich obywateli obowiązywało jednakowe prawo i sprawiedliwość. Wszyscy korzystali $\mathrm{z}$ tych samych instytucji politycznych. Oznaczało to osiągnięcie wyższego pozio$\mathrm{mu}$ w procesie tworzenia cywilizacji europejskiej, która zmierzała do zrzeszenia narodów. Działalność Napoleona wdrażała w życie zasadę zrzeszenia się narodów, a przez to zwiększała uspołecznienie rodu ludzkiego. Była ona zgodna z myślami i życzeniami wielu uczonych i monarchów o wielkiej Lidze Europejskiej. Złączone pod jednym berłem narody zaczęły tworzyć Ligę Reńską, mogły poznać prawdziwe szczęście i pokój w skonfederowanej Europie. Ale na drodze dalszego rozwoju cywilizacji europejskiej i umacniania się politycznego związku narodów europejskich i powszechnego pokoju stanęły duma, egoizm, zazdrość oraz żądza panowania. Anglicy i Rosjanie, wspierani przez północną Azję, wkroczyli do Europy, aby unicestwić dzieło zjednoczenia, wypowiedzieli wojnę postępującej cywilizacji. Bliski powstania związek państw europejskich, czyli zrzeszenie narodów europejskich, mógł na trwałe zatrzymać azjatycką nawałnicę, zniszczenie cywilizowanych krajów, wtrącanie się do rządów europejskich ${ }^{20}$.

Według S. Staszica azjatyckie barbarzyństwo stanowi największe zagrożenie cywilizacji i pokoju w Europie. Sami Europejczycy po raz trzeci zniszczyli dzieło jednoczenia się. Carowie moskiewscy wspólnie z Europejczykami już zniszczyli Królestwo Polskie - przedmurze Europy. Na zawołanie mają nieucywilizowane ludy Azji, których nie trzeba zanadto zachęcać do rabowania Europy. Mężni Polacy, przysposobieni do niewygód, zimna i wojny, przez wieki strzegli granicy Europy. Autor Rodu ludzkiego przestrzegał mieszkańców Starego Kontynentu, że usilne wciąganie ludów Azji do Europy okaże się ich zgubą. Polska już doświadczyła podstępu i grabieży. Inne narody też ulegną ludom Azji, gdy tylko zostaną wpuszczone. Niszcząc Polskę, wpuściły Moskwę w głąb Europy ${ }^{21}$.

Gwarantem bezpieczeństwa i pokoju jest wielka liga narodów Europy. W zamian za utratę niezależności zewnętrznej zrzeszone kraje zyskują niepodległość prawną oraz pokój. Efektem powstania zrzeszenia będzie ustanowienie porządku

20 Por. ibidem, s. 310-316.

21 Por. ibidem, s. 316-319. 
wewnętrznego, ograniczenie egoizmu i przekupstwa, a także rozwój całej gospodarki, m.in. całego przemysłu i handlu ${ }^{22}$.

Czwartą próbę zjednoczenia Europy podejmą - zdaniem S. Staszica - narody słowiańskie. Inicjatorem może być Rosja, która otrzyma wsparcie narodów pobratymczych, m.in. z Polski, Czech i Chorwacji. Narody te są gotowe do ścisłych związków z Rosją. S. Staszic zastanawiał się, czy droga ta okaże się równie zgubna, czy tysiące lat pracy zostaną ponownie zmarnowane. Narody Europy były ciągle rozrywane, poróżniane i wciągane do wojny, chociaż tak bliskie było ich zjednoczenie. Autor Rodu ludzkiego stał jednak na stanowisku, że przeznaczeniem ludzkości jest zrzeszenie Europy, które dokona wielki naród Słowian. W idei zrzeszenia tkwi jakaś ukryta siła, która przez tysiące lat pociągała do działania ${ }^{23}$.

\section{ZAKOŃCZENIE}

Przeniknięty ideami oświecenia S. Staszic opublikował szereg memoriałów i prac politycznych, wychowawczych, historycznych i filozoficznych, w których zawarł swoje poglądy ekonomiczne. Domagał się przeprowadzenia radykalnych reform systemu oświaty oraz ustroju społeczno-politycznego, m.in. likwidacji przywilejów szlacheckich oraz uwolnienia chłopów od pańszczyzny. Przeciwstawiał się ubóstwu klas uciskanych oraz bogactwu i próżnowaniu uprzywilejowanych. W rolnictwie - wzorem fizjokratów - widział źródło bogactwa, rozumiał znaczenie wolności, własności i pracowitości. Jednocześnie proponował rozwój przemysłu, wspierany przez protekcjonistyczną politykę państwa oraz tworzenie - jako bardziej efektywnych - mniejszych gospodarstw rolnych. Przedstawiając dzieje cywilizacji ludzkiej niemal 100 lat przed T. B. Veblenem, obnażył barbarzyńską naturę człowieka i główne motywy jego działalności. Uważał, że przywileje i bogactwo stanu szlacheckiego są efektem podstępu, oszustwa, grabieży i wyzysku. Bezproduktywna szlachta i duchowieństwo utrzymywane są przez ciemiężone chłopstwo.

Doświadczona wojnami i niesprawiedliwością ludzkość w piątej fazie swego rozwoju dojrzeje do zjednoczenia. S. Staszic okazał się pierwszym w Polsce autorem idei zjednoczonej Europy. Zrzeszenie narodów Europy zlikwiduje konflikty międzynarodowe oraz zapewni rozwój społeczno-gospodarczy wszystkim zrzeszonym narodom. Polski myśliciel uważał, że w zjednoczonej Europie - wzorem zjednoczonego cesarstwa chińskiego - nastąpi niewyobrażalny rozwój całej gospodarki, zapewniający szczęście wszystkim mieszkańcom.

22 Por. ibidem, s. 319.

23 Por. ibidem, s. 320-321. 


\section{BIBLIOGRAFIA}

Bobińska C., Wstęp, [w:] S. Staszic, Wybór pism, Spółdzielnia Wydawnicza „Książka”, Warszawa 1948.

Chyra-Rolicz Z., Stanistaw Staszic, PWN, Warszawa 1980.

Grzywicka J., Ekonomiczne poglady Stanistawa Staszica, PWN, Warszawa 1957.

Iłowiecki M., Dzieje nauki polskiej, Wydawnictwo Interpress, Warszawa 1981.

Limanowski B., Stanistaw Staszic: życiorys, Wydawnictwo J. Mortkowicza, Warszawa [1920].

Łotys Z., Stanistaw Staszic - fllozof i reformator spoteczny, seria „Studia i Materiały WSP w Olsztynie” nr 158, Wyższa Szkoła Pedagogiczna, Olsztyn 1999.

Machlup F., Integracja gospodarcza - narodziny i rozwój idei, PWN, Warszawa 1986.

Olejniczak J., Stanistaw Staszic 1755-1826: jubileusz 250. rocznicy urodzin, Archiwum PAN, Warszawa [2005].

Płaczek J., Poczet wybitnych ekonomistów polskich XVIII-XX stulecia, Akademia Obrony Narodowej, Warszawa 2000.

Rutkowska I., Od wspólnot europejskich do unii europejskiej, cz. 1: Ekonomiczne i prawne podstawy oraz ewolucja integracji zachodnioeuropejskiej, Wydawnictwo Zachodniopomorskiej Szkoły Biznesu, Szczecin 1998.

Stownik biograficzny ekonomistów polskich od XIII wieku do potowy wieku XX, zebrał i oprac. Z. Gazda, Wyższa Szkoła Pedagogiczna im. J. Kochanowskiego w Kielcach, Kielce 1998.

Staszic S., Ród ludzki, t. 1-3, oprac. Z. Daszkowski, przedmowę napisał B. Suchodolski, PWN, Warszawa 1959.

Szacka B., Stanistaw Staszic. Portret mieszczanina, Wiedza Powszechna, Warszawa 1962.

Szacka B., Teoria i utopia Stanistawa Staszica, PWN, Warszawa 1965.

Szacka B., Stanistaw Staszic, Państwowy Instytut Wydawniczy, Warszawa 1966.

\section{STRESZCZENIE}

Stanisław Staszic był wychowawcą i mężem stanu, tłumaczem, pisarzem politycznym, filozofem, działaczem gospodarczym, filantropem, pacyfistą, podróżnikiem i geologiem. Dzięki spekulacjom i oszczędnościom zgromadził milionowy majątek, który przeznaczył na cele publiczne. W opublikowanym w latach 1819-1820 (a pisanym w latach 1791-1814) poemacie dydaktycznym pt. Ród ludzki S. Staszic przedstawił nie tylko fazy rozwoju ludzkości, ale również - jako pierwszy w nauce polskiej - ideę zrzeszenia powszechnego narodów. Chociaż wcześniejsze próby zjednoczenia Europy (podejmowane przez starożytnych Greków, Rzymian, Karola Wielkiego i Napoleona Bonaparte) zakończyły się fiaskiem, narody europejskie dojrzały od nowej organizacji politycznej. S. Staszic uważał, że zrzeszenie narodów zapewni trwały pokój oraz stworzy warunki do rozwoju całej gospodarki. 


\title{
STANISŁAW STASZIC - THE POLISH PIONEER OF THE IDEA OF EUROPEAN INTEGRATION
}

\begin{abstract}
SUMMARY
Stanisław Staszic was an educator and statesman, translator, political writer, philosopher, economic activist, philanthropist, pacifist, explorer, and geologist. Thanks to speculation and savings, he accumulated property worth millions, which he earmarked for public purposes. In a didactic poem entitled Ród ludzki (The Human Race), published in the years 1819 to 1820 (and written in the years 1791 to 1814), S. Staszic not only presented the phases of human development, but also - as the first amongst Polish scholars - the idea of a general association of nations. Although earlier attempts to unite Europe (taken by ancient Greeks, Romans, Charlemagne and Napoleon Bonaparte) had ended in fiasco, European nations had reached a point where a new political organization could be achieved. S. Staszic believed that the association of nations would ensure sustainable peace and create conditions for the development of the economy.
\end{abstract}


